\title{
Kernos
}

Revue internationale et pluridisciplinaire de religion grecque antique

$29 \mid 2016$

Varia

\section{Shaping Ceremony. Monumental Steps and Greek Architecture}

Hedvig von Ehrenheim

\section{OpenEdition}

\section{Journals}

Electronic version

URL: http://journals.openedition.org/kernos/2443

DOI: 10.4000/kernos.2443

ISSN: 2034-7871

\section{Publisher}

Centre international d'étude de la religion grecque antique

\section{Printed version}

Date of publication: 1 October 2016

Number of pages: 463-465

ISSN: 0776-3824

\section{Electronic reference}

Hedvig von Ehrenheim, « Shaping Ceremony. Monumental Steps and Greek Architecture », Kernos

[Online], 29 | 2016, Online since 01 October 2016, connection on 21 November 2020. URL : http:// journals.openedition.org/kernos/2443; DOI : https://doi.org/10.4000/kernos.2443

This text was automatically generated on 21 November 2020.

Kernos 


\title{
Shaping Ceremony. Monumental Steps and Greek Architecture
}

\author{
Hedvig von Ehrenheim
}

\section{REFERENCES}

Mary B. HOLLINSHEAD, Shaping Ceremony. Monumental Steps and Greek Architecture, Madison, The University of Wisconsin Press, 2015. 1 vol. $21 \times 26 \mathrm{~cm}$, xiv+233 p. ISBN :

978-0-29-9301101.

1 Altars and temples are designed to accommodate gods. Theatral steps, dining rooms, hostels, baths and latrines are designed to accommodate people. Monumental stairways may also shape the movement of a procession. Mary B. Hollinshead (M.B.H.)'s book collects and analyses a wide range of material on the social use of steps, material which has been discussed separately in various excavation publications.

2 The book focusses on monumental steps in stone which were built to be permanent and which were constructed independently of other buildings. Steps that are "theatral" because they were intended to enhance seeing and hearing are included here, but clearly defined or "purpose built" theatres or assembly buildings are excluded. The material at hand comes primarily (but not exclusively) from Greek sanctuaries in the Aegean region, and their dates of construction range from Archaic times to the second century BC.

3 The book has 233 pages distributed over eight chapters and an appendix covering grand steps in Hellenistic Italy, as well as a catalogue of sites and plates covering 44 sites (101 plates in total). The catalogue, index, plates and bibliography are very helpful and easy to use, and the footnotes are to the point and never too long. The first three chapters consider the biomechanics of walking and sitting (in order to determine the most likely use of the steps), theoretical observations on the dynamic relationship between architecture and ritual, as well as the social effects and political consequences of directing a walk to lead to a particular focal point or creating space for a gathering. 
Chapters four to eight survey the details of grand steps in Greek sanctuaries through Archaic times, and then into the second century.

4 The actual and most likely use of the steps (sitting, standing), the focus of their point of view, as well as monumental steps leading to the focal point of the ritual are analyzed. The steps are put into the overall planning of the larger architectural unit and literary and epigraphical testimonia on the steps or grandstands are considered where available. Also the historical background to the building schemes of the sites is studied. The material is not easy to categorize, and many times, of course, multifunction use must be assumed. Given the wide range and possible uses of the material, the A. is prudently tentative in her conclusions.

5 The method of M.B.H. is to pay minute attention to the detail of the material at hand, first of all the measurements and placement of the steps (close to the altar, temple, paved courtyard). Could they have been used for sitting, standing (in order to give all spectators a better view), or for example, could the presence of a railing at the lowest step indicate viewing facilities?

6 The A. has wisely avoided using the names of the Archaic, Classical or Hellenistic periods as those would tend to induce the premature conclusion of a sense of style being at work when constructing these monumental steps. To have this unbiased methodological approach is useful for instance when discussing the steps at Kos, which have often been seen as a prime example of the monumental dramatic style of Hellenistic times, but which, upon closer inspection, are shown to have developed from previous forms of ascent by way of a ramp.

7 Generally, scholars have previously believed that the monumental use of steps came to Greece from ninth through sixth century Eastern prototypes or even Aegean Bronze Age predecessors (whereas the ramps that were used in Archaic Greece were supposedly a non-related form of architecture). The A. concludes convincingly that monumental steps, as they appear in the sixth century sanctuaries, developed independently from Bronze Age steps or eastern forms. The way in which this book acknowledges the preceding incremental development at each site is a great achievement.

8 Contra the previous general assumption that the monumental nature of these steps was an assertion of political dominance, M.B.H. argues that the grand steps of the Greek world are fundamentally communal in nature. They are monumental, yes, but their monumentality is not a goal in and of itself; the steps are used to enhance the social experience and status of both the sanctuary and those participating in its rituals. M.B.H. speaks of a "collective enthusiasm". As for the monumental steps leading up to the central foci of the cult, as, for instance, at Kos, she offers an interesting discussion of the ways in which the structure of monumental steps must have shaped and cemented parts of the procession order and rhythm. As for Hellenistic Italy (Gabii, Pietrabbondante, Tivoli), however, the A. draws the conclusion that the monumental steps served more to impress by their monumentality than to fulfil an actual ceremonial function. Possibly, she writes, wealthy Romans visited sites as Pergamon and Lindos, and being impressed by what they saw, reproduced the splendor at home, without adding the Greek ceremonial function of the steps.

9 Given the large scope of the investigation this is not a book which you will read straight through following one argument. Rather, it is an excellent study which, through the presentation of a careful analysis of the evidence, shows you how sanctuaries were 
planned and built for the people coming there. It shows you how it is possible, through a meticulous study of the archaeological evidence, to fill the sanctuary with people and their participation in ceremonies. The book makes us think in new ways when looking at the architectural plan of a sanctuary and compels us to consider the role of the obvious and therefore unseen (how grand steps and paved courts shaped and made uniform rituals) as well as showing the fundamentally communal nature of Greek sanctuaries. The book also explains the scale of activities at sanctuaries, which can be demonstrated by the archaeological material. For instance, it illustrates how Greek sacrifice at festivals was a public spectacle (steps encompassing altars). All in all, it is a very useful and easy-to-use tool for those who want to examine the possibilities of larger group rituals and ceremonies at a wide range of sanctuaries across the Greek world.

\section{AUTHORS}

\section{HEDVIG VON EHRENHEIM}

University of Uppsala 